\title{
動的破壊勒性解析へのローカルアプローチの適用 とその問題点
}

\author{
正員田川哲 哉* 正員島 貫 広 志** \\ 正員萩原行人 $* *$ 正員宮田隆 司*
}

\begin{abstract}
Application of Local Fracture Criterion Approach for Dynamic Fracture Toughness
\end{abstract}
by Tetsuya Tagawa, Member Hiroshi Shimanuki, Member

Yukito Hagiwara, Member Takashi Miyata, Member

\begin{abstract}
Summary
Influence of dynamic loading on the fracture toughness of steels has been investigated analytically and experimentally. Stress singularity at a crack tip and applicability of fracture mechanics parameter have been discussed with dynamic FEM analysis. An augmentation of the stress field due to the increase of loading rate could be successfully normalized with the yield strength referred to the rate-temperature parameter; $\mathrm{R}$ at a particular location near the crack tip. The Weibull stress obtained by the stress integration around the crack tip for the applied stress intensity factor $K$ could be also normalized with the reference yield strength independent on the loading rate. These results imply that the dynamic fracture toughness can be described with $\mathrm{R}$ parameter at a specified location near the crack tip.

The transition behavior of fracture toughness $K c(J c)$ under static, quasi-static and dynamic loadings were investigated for four kinds of steels with different strengths. Lower strength steel showed more significant enbrittlement due to the increase of the loading rate, as is previously reported. Predictions of the fracture toughness under quasi-static and dynamic loading was examined with the Local Fracture Criterion Approach. As a measure of loading rate, $\mathrm{R}$ parameter evaluated from elastic strain distribution was taken for simplification. The experimental fracture toughnesses $K c(J c)$ smaller than $100 \mathrm{MPam}^{1 / 2}$ were well described with the simplified prediction. The predicted values for the larger fracture toughness, however, were too conservative. This may be due to the constraint loss around the crack tip and/or the heat effect by plastic work and/or the dynamic effect on the cleavage fracture strength.
\end{abstract}

\section{1. 緒言}

阪神淡路大震災以来, 破壊勒性の負荷速度依存性が再び 注目されるようになってきている1)。負荷速度が鋼材の機 械的性質に対して及ぼす影響は降伏応力に対して顕著であ り,ひずみ速度と温度を取り达んだひずみ速度一温度パラ メータ (Rate-Temperature parameter ; 以下 R と呼ぶ) ${ }^{2)}$ よる整理がなされている。しかし, 破壊勒性を考える場 合, き裂先端で一定でないRの取り扱いやき裂先端での塑 性仕事による断熱昇温の影響 ${ }^{3,4)}$ ，あるいはそれらによりき

* 名古屋大学工学研究科材料機能工学専攻

** 新日本製鐵（株）鉄鋼研究所

原稿受理 平成 11 年 1 月 8 日

春季講演会に扔いて講演 斗成 11 年 5 月 12,13 日
裂先端で生じる構成式変化が応力場に及ほす影響など,動 的破壊勒性を考える上では未解決な問題が多い。問題点を 整理すると,

(1)「動的負荷と静的負荷において，J,Kあるいは $\delta$ といっ た破壊力学パラメータによりき裂先端の応力場の等価性は 保証できるか。」

(2)「動的負荷と静的負荷において, 破壊条件（破壊に対す る応力条件) は一定であるか。」

これらの問題は，動的破壊勒性を静的問題と同様にJ $J, K c$ あるいは $\delta_{c}$ で評価でき得るかという基本的な問題である。

一方，豊貞 5 ${ }^{5,6)}$ や金田ら7)を始めとして, 動的破壊勒 性がき裂先端のある特定の位置あるいは領域におけるRを 用いてある程度整理できるといった報告8)もるが, あく までも実験的な整理であり, き裂先端での $\mathrm{R}$ の変化を考え 合わせると, その理論的根拠が明確でない。従って,

(3)「破壊勒性に対するRの物理的意味の解明」が必要とな 
る。

一方，著者らはこれまで鋼のへき開破壊が基本的に材 料の変形条件と破壊条件により決まるという立場（ロー カルアプローチ9)）から，静的破壊勒性に対して理論的 . 実験的検討を行ってきた10,11)。本研究では, 強度の異なる 4 種類の材料に対して破壊勒性の变位速度依存性の検討 を行うとともに，弾塑性動的有限要素法（D-FEM）を用 い, 負荷速度の増加に対するき裂先端応力場の変化を検 討するとともに，ローカルクライテリオンアプローチを 適用し ${ }^{12)}$, 上記の 3 つの問題の解明を試みた。さらにロー カルアプローチに基づいた破壊勒性評価式10.11)を用いて, 負荷速度増加による勒性変化を簡易的に推定する手法を 検討するとともに，そこでの問題点を検討した。

\section{2. 供試材および実験方法}

供試材は 4 種類の鋼材で，化学成分を Table 1 に，機械 的性質を Table 2 に示す。破壊勒性はASTM E1820に準拠 し板厚 1 インチのCT 試験片を用い $J$ 積分で評価した。実 験結果の解析では, 平面ひずみ状態を仮定し $J c$ を $K c$ に換 算して示している。変位速度は $0.005,1,500 \mathrm{~mm} / \mathrm{sec}$ の 3 水準とし，各变位速度に扔ける遷移曲線を測定した。

各供試材の降伏応力 $\sigma_{y s}$ は, Fig.1(a)に示寸砂時計型丸

Table 1 Chemical composition of steels tested (mass\%).

\begin{tabular}{lccccc}
\hline & C & Si & Mn & P & S \\
\hline SM400B & 0.17 & 0.19 & 0.69 & 0.028 & 0.010 \\
SM490B & 0.16 & 0.44 & 1.34 & 0.013 & 0.004 \\
SA440 & 0.14 & 0.24 & 1.44 & 0.011 & 0.002 \\
HT780 & 0.11 & 0.22 & 0.84 & 0.010 & 0.002 \\
\hline
\end{tabular}

Table 2 Mechanical properties of steels tested.

\begin{tabular}{lccc}
\hline & $\sigma_{y s}, \mathrm{MPa}$ & $\sigma_{u t s}, \mathrm{MPa}$ & R.A. \\
\hline SM400B & 289 & 483 & 0.65 \\
SM490B & 343 & 593 & 0.67 \\
SA440 & 489 & 582 & 0.73 \\
HT780 & 777 & 826 & 0.76 \\
\hline
\end{tabular}

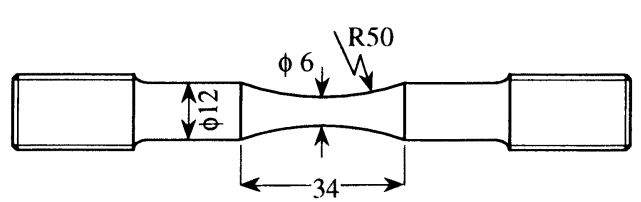

(a) Smooth round bar tensile specimen.

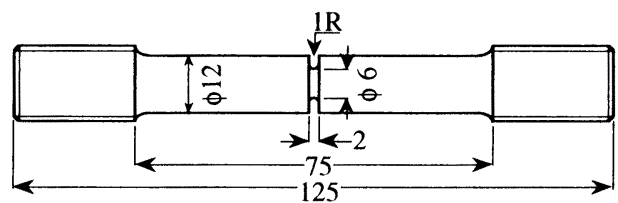

(b) $1 \mathrm{mmR}$ notched round bar tensile specimen.

Fig.1 Configuration of tensile specimens. (dimensions are in $\mathrm{mm}$ )
棒試験片の最小断面部に貼付したひずみゲージにより測 定された $0.2 \%$ 耐力を用いた。 $10^{-3} \sim 10^{3} \mathrm{~mm} / \mathrm{sec}$ の間の 4 水 準の変位速度において, 室温から $-196^{\circ} \mathrm{C}$ に渡る数温度で 実験を行い, 各変位速度における降伏応力の温度依存性 を評価した。各試験片のひずみ速度と試験温度を基にひ ずみ速度一温度パラメータ（R）を算定したが，ひずみ速 度はひずみゲージにより測定した弾性域から降伏初期段 階の值を用いた。温度はひずみゲージをはさむ 2 力所に 取り付けた熱電対で測定した值を用いた。Rは次式の定義 を用いた。

$$
\mathrm{R}=\mathrm{T} \ln (\mathrm{A} / \dot{\varepsilon}), \mathrm{K} \ldots \ldots \ldots(1)
$$

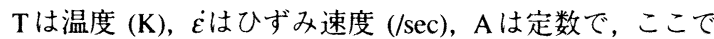
は $10^{8}$ 一定とした5)。

へき開破壊強度はFig.1(b)に示す $1 \mathrm{mmR}$ 円周切欠き丸棒

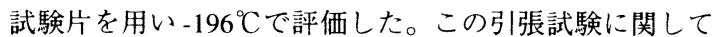
も $10^{-4}, 10^{-2}, 15 \mathrm{~mm} / \mathrm{sec}$ の 3 種類の変位速度で試験を行い, 破壊強度の変位速度依存性を検討した。へき開破壊強度 の評価に際しては, 後述する動的有限要素法により算定 される試験片破壊時の Weibull 応力 $\left(\sigma_{w, c r}\right)$ および最大主 応力 $\left(\sigma_{c}\right)$ の 2 種類 ${ }^{111}$ を用いた。

き裂材, 切欠き材の応力解析には動的有限要素法 (DFEM）を用い, Weibull応力の解析やき裂先端の応力分布， $\mathrm{R}$ の分布について検討を行った。D-FEMは 8 節点アイソ パラメトリック 4 角形要素を用いた有限変形 2 次元問題 (CT 試験片：平面ひずみ, $1 \mathrm{mmR}$ 切欠き丸棒：軸対象）と して解いた。特に解析精度上の問題となる CT 試験片の メッシュ分割図をFig.2 に示す。ここでは切欠き底半径 $5 \mu \mathrm{m}$ の切欠きを疲労き裂と見なしている。計算手法は豊 貞ら の行った方法を参考に，簡易化した手法を用いた。 すなわち, FEM計算における各ステップの流動応力は材 料の構成式を介してひずみ速度と相互に関連するため, 正確には豊貞ら ${ }^{4)}$ が行ったように収束計算を用いて一連 の関係を満足する $\mathrm{R}$ を基に決定すべきであるが，ここで

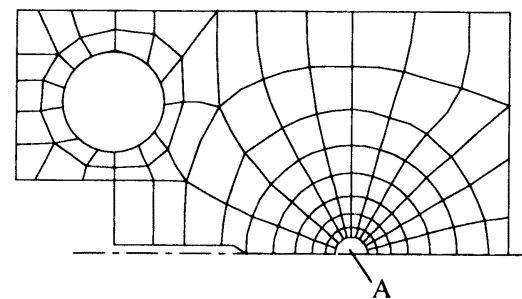

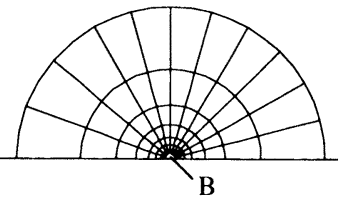

Detail in A

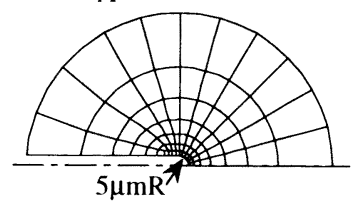

Detail in B
Fig.2 Finite element mesh for CT specimen. 


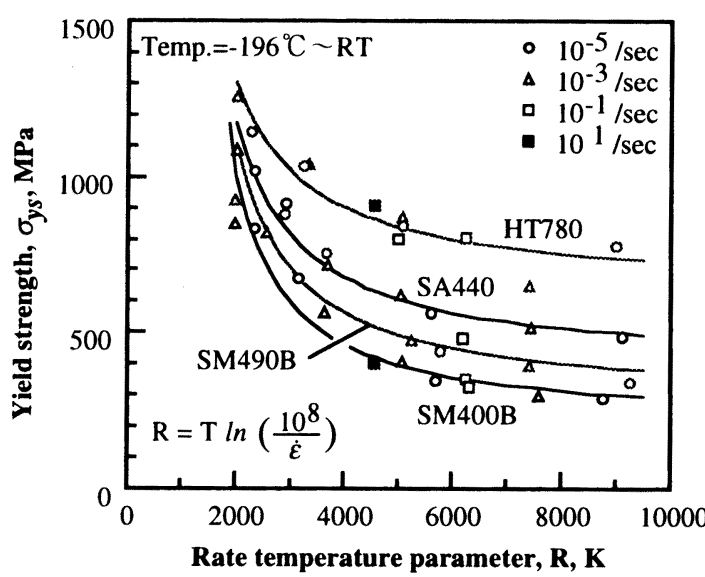

Fig.3 Relation between yield strength, $\sigma_{y s}$ and rate-temperature parameter, $\mathrm{R}$ for steels tested.
は簡単のため増分計算を用いた。また, $\mathbf{R} の$ 算定には塑性 仕事による昇温は考慮したが，熱伝導は現象が高速であ ることからここでは無視した。そのため，宅が $10^{-3} / \mathrm{sec}$ り小さい場合は場合は発熱はないものとした。発熱量の 算定は塑性仕事の 90\%が熱に変換されるものと仮定し4), エネルギー変換係数, 比熱などの值は豊貞ら ${ }^{4)}$ と同じ值 を用い温度に換算した。この昇温に伴う熱ひずみは無視
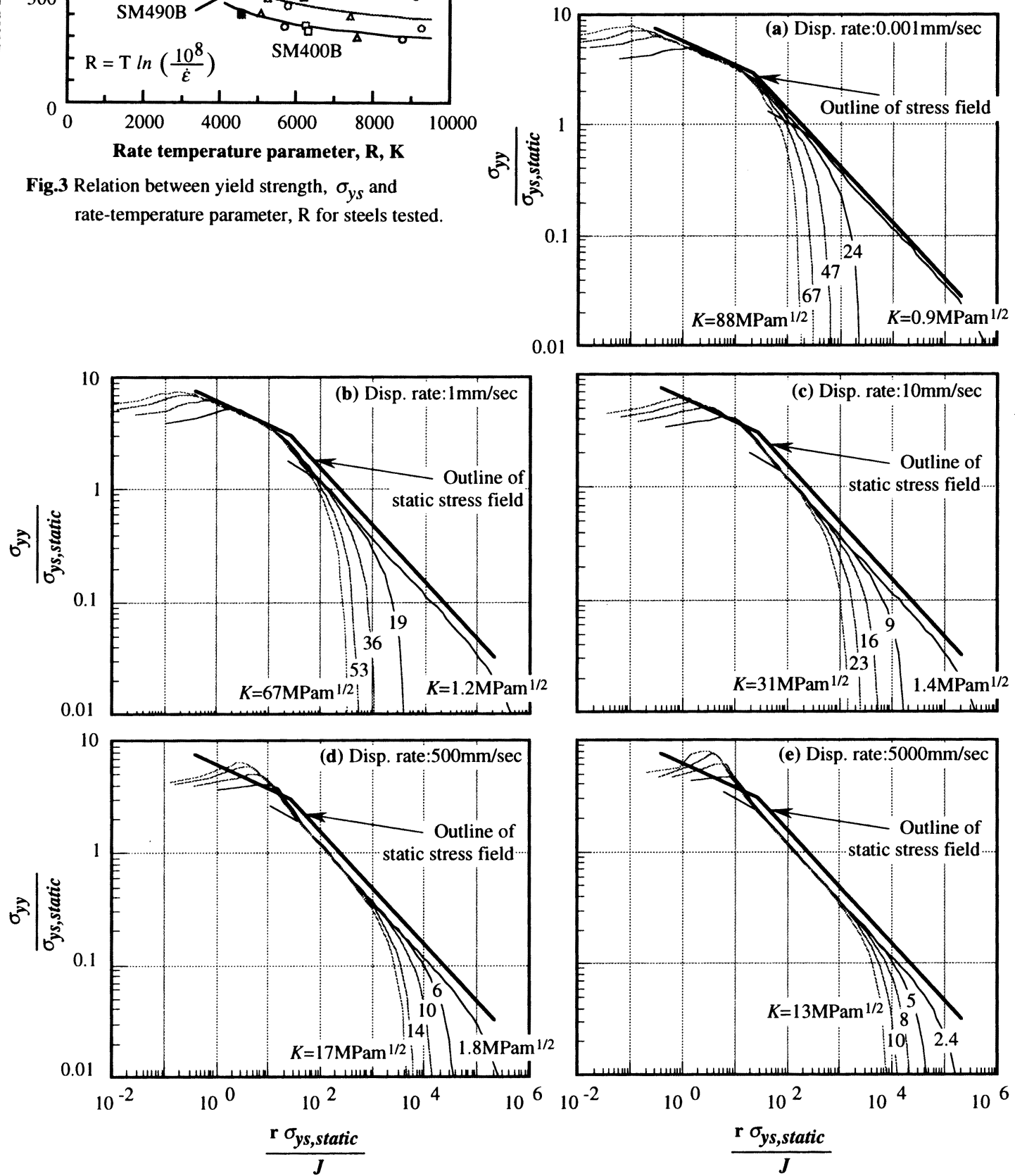

Fig.4 Normalized stress distributions along crack line for displacement rate from $0.001 \mathrm{~mm} / \mathrm{sec}$ to $5000 \mathrm{~mm} / \mathrm{sec}$ (1T-CT, $-50{ }^{\circ} \mathrm{C}, \mathrm{SM} 400 \mathrm{~B}$ ). 
したが，昇温の著しい位置では熱ひずみに比較してはる かに大きな塑性ひずみを生じていることから，妥当であ ると考えられる。この昇温量とひずみ速度を基に次ス テップの Rパラメータを算定し, 降伏応力 $\sigma_{y s}$ を決定し た。そこで必要となる $\sigma_{y s} \mathrm{R}$ 関係は各供試材の実験結果を 基に次式で近似した関数を用いた。

$$
\sigma_{y s}=\mathrm{C}_{1} \exp \left(\mathrm{C}_{2} / \mathrm{R}\right)
$$

$\mathrm{C}_{1}, \mathrm{C}_{2}$ は材料定数である。材料の構成式は後藤ら ${ }^{13)}$ の方 法と同様に，(2) 式で算定された降伏応力を基に参照した 硬化指数 $n$ を用いた $n$ 乗硬化則で与えた。

\section{3. 実験結果}

\section{1 動的負荷に伴うき裂先端の応力場の変化}

各供試材の降伏応力を R で整理した結果を Fig.3に示 す。ややバラッキもあるが, 異なる温度, ひずみ速度の下 で評価した降伏応力は $\mathrm{R}$ パラメータで一義的に整理でき ることがわかる。また, 従来から言われているように, 強 度の低い材料ほど $(\mathrm{SM} 400 \mathrm{~B})$ 降伏応力の $\mathrm{R}$ 依存性が大き いことがわかる。図中の曲線はこれらの実験結果を(2)式 で近似した関数である。

Fig.4にD-FEMにより得られたCT 試験片のき裂線上の 応力分布を無次元化距離に対して示す。応力あるいは $J$ 積 分の無次元化には便宜的に静的な $\left(\dot{\varepsilon}=10^{-5} / \mathrm{sec}\right)$ 降伏応力 を用いた。ここで用いた FEメッシュでは切欠き底半径 $5 \mu \mathrm{m}$ の切欠きをき裂と見なしているため，き裂先端に除 荷領域が見られるが, 静的（変位速度：0.001 mm/sec）負 荷の結果（Fig.4(a)）には弾性特異応力場, HRR 特異応力 場が明瞭に見受けられる。变位速度が早くなるにつれて, 応力場の特異性は強まり, 弾性特異応力場あるいは直線 硬化の特異応力場に近い状況に遷移していくことがわか
る $($ Fig.4(b) $\rightarrow(\mathrm{c}) \rightarrow(\mathrm{d}) \rightarrow(\mathrm{e}))$ 。比較のために, Fig.4(b), (c), (d), (e)には静的な結果（Fig.4(a)）も合わせて示している が, 負荷速度増加に伴い応力特異性が遷移した結果, き裂 先端の応力は静的状態に比較して高くなっていることが わかる。材料の破壞条件 (限界応力) が負荷速度に依存す るか否かを議論する必要はあるが，このき裂先端での高 応力が動的負荷での脆化の主因であると考えられる。動 的負荷により，このような応力特異性を示す理由の詳細 は現在検討中であるが，ひずみレベルの大きなき裂先端 ではひずみ速度も大きくなり，材料の構成式が直線硬化 に近づいたことによるものと考えられる。

Fig.5にき裂線上に扔けるR 分布の負荷に伴う変化をき 裂先端からの距離に対して示す。き裂の極先端では塑性 仕事による発熱の影響が顕著であり,Rは負荷とともに上 昇して行くが，豊貞ら出が指摘しているようにRはき裂先 端から $100 \mu \mathrm{m}$ 程度の位置に棚（豊貞らの言う $\mathrm{R} \gamma$ ）を生じ る分布となっていくことがわかる。豊貞らはこの棚の值 $\mathbf{R} \gamma$ を負荷速度レベルの指標として用いると, 破壊勒性に 及ほすすひずみ速度の影響がよく整理できるとしている5。 本研究ではこの特定の位置における $\mathrm{R}$ の持つ意味を明ら かにしようとするものあるが, 棚の值 $(\mathrm{R} \gamma)$ はJとともに 変化するため算定が煩雑であること，動的勒性問題で議 論となるのは指数乗で異なるような大きな負荷速度变化 であることから，ここでは簡単のために弾性状態での R 分布を基にき裂先端から $100 \mu \mathrm{m}$ の位置における $\mathrm{R}$ ， $\mathrm{R}_{e l s, \mathrm{X}=100 \mu \mathrm{m}}$ を負荷速度レべルの指標として用いることに する。き裂先端の弾性状態の $\mathrm{R}$ 分布は, ひずみ分布の解 析解を基に外的負荷条件寸なわち $d K / d t$ から容易に求める ことが可能である。また，き裂先端からの距離として特定 した $100 \mu \mathrm{m}$ という值は, 勒性試験片破面に観察された破 壊起点が予き裂端 $50 \mu \mathrm{m}$ から $800 \mu \mathrm{m}$ の範囲（Fig.5 中の墨

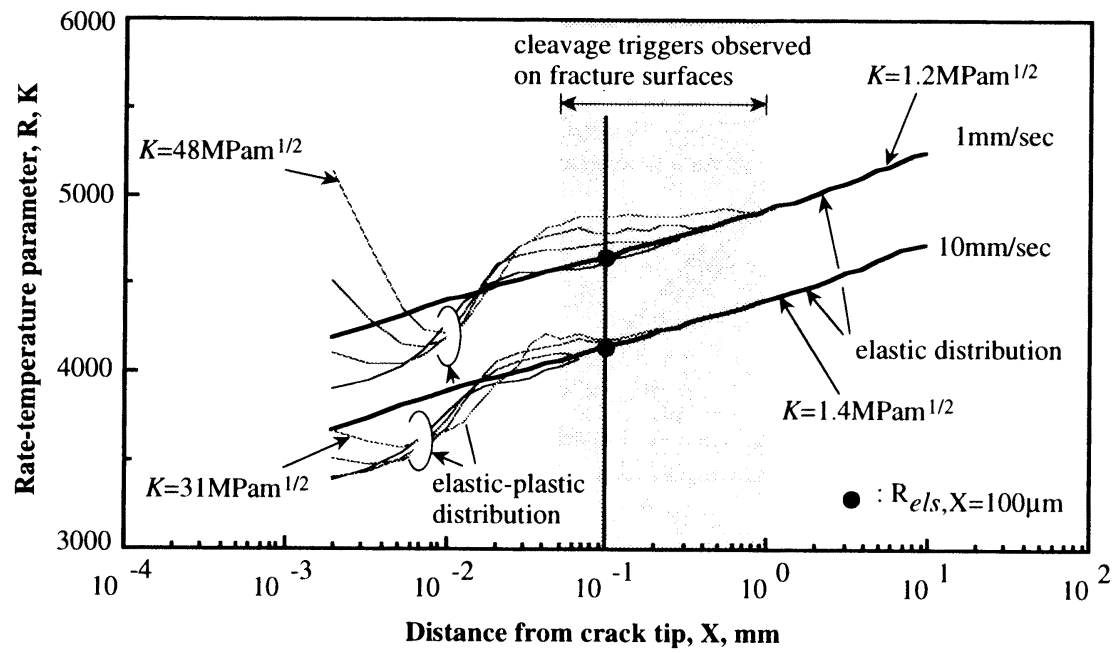

Fig.5 R distributions on crack line obtained by D-FEM for SM $400 \mathrm{~B}$ at $-50{ }^{\circ} \mathrm{C}$. 


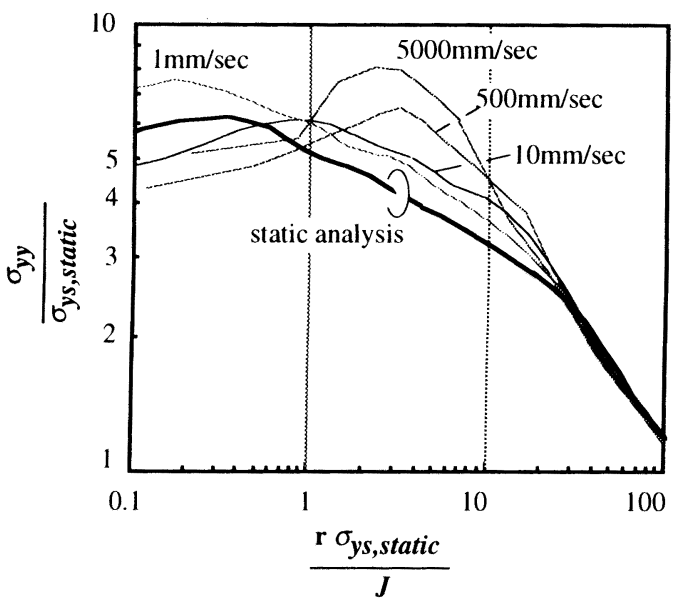

(a) Stress distributions normalized with static yield stress

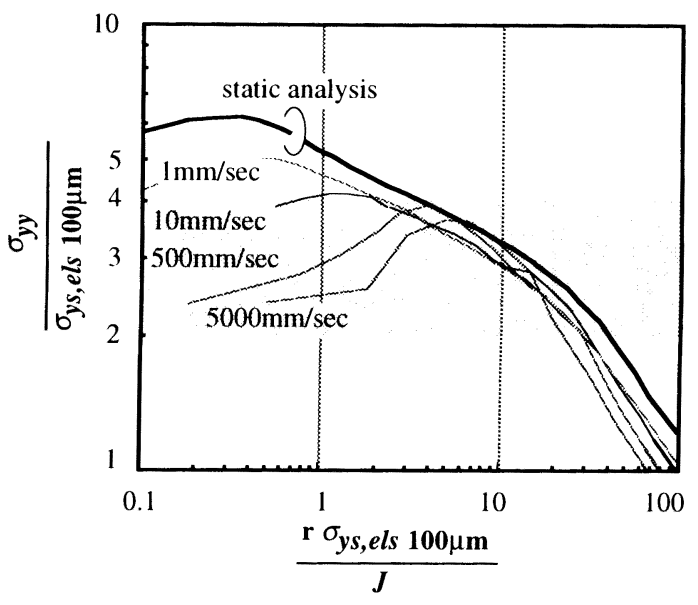

(b) Stress distributions normalized with dynamic yield stress estimated from $\mathrm{R}_{e l s, \mathrm{X}=100 \mu \mathrm{m}}$

Fig.6 Normalized stress distributions along crack line (1T-CT, $\left.-50^{\circ} \mathrm{C}, \mathrm{SM} 400 \mathrm{~B}\right)$

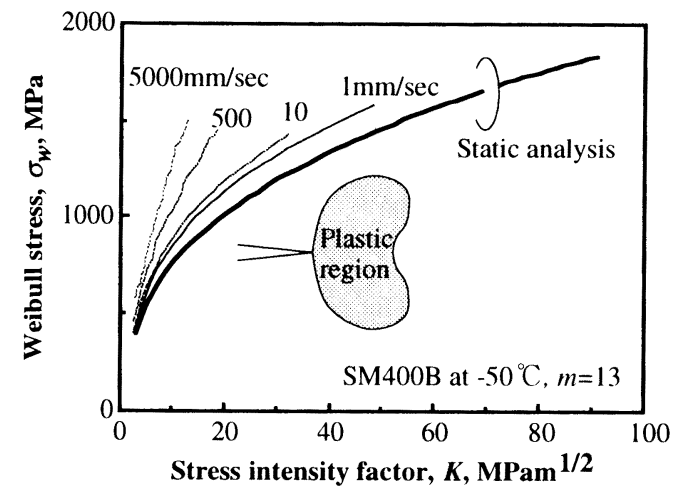

(a) for Weibull stress $\sigma_{w}$

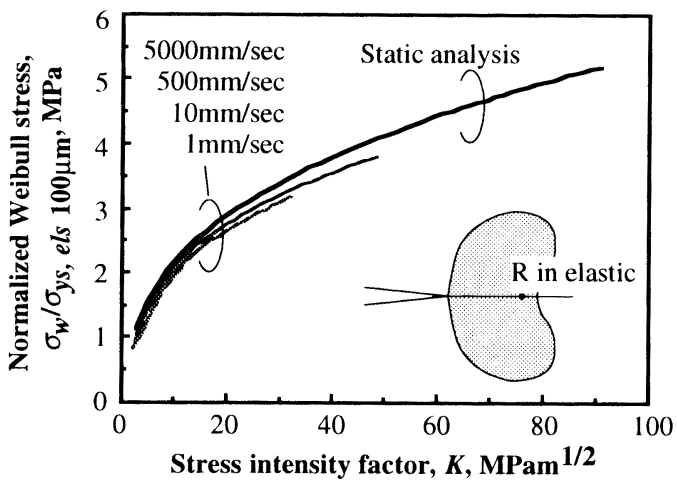

(b) for normalized Weibull stress $\sigma_{w} / \sigma_{y s}$, els $100 \mu \mathrm{m}$

Fig.7 Relation between Weibull stress $\sigma_{w}$ and stress intensity factor $K$ for displacement rates from $10^{-3}$ to $5 \times 10^{3} \mathrm{~mm} / \mathrm{sec}$ (1T-CT, SM400B, $-50^{\circ} \mathrm{C}$ ).

塗り部分）に分布していること，この範囲で $R$ 分布が棚 を形成することから便宜的に定めた。これを仮に $200 \mu \mathrm{m}$ や300 $\mu \mathrm{m}$ としても，あるいは負荷に応じて多少増大させ たとしても，後の考察にほとんど差異は生じない。 Fig.6(a)はFig.4(a) 〜 (e) までの各変位速度の結果の高応力 となる部分のみを同時に示したものであり，既に述べた ようにき裂先端近傍応力の絶対值が負荷速度の増大に伴 いかなり高くなることを示している。一方, Fig.6(b)はき 裂先端から $100 \mu \mathrm{m}$ の位置における弾性変形における $\mathrm{R}$,

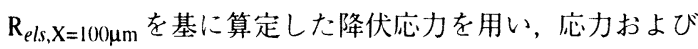
Jの無次元化を行った結果である。Fig.6(b) の結果による と, 破壊の起こり得る降伏応力の $2-4$ 倍の高応力域に おいて, いずれの変位速度に掞いても無次元化応力はほ ほ一致しておりここうした無次元化によりる積分を用いた 応力場の記述が動的問題でも可能なことを示している。
すなわち, $J$ 積分は動的問題に対しても単一の応力場パラ メータとしての意味を有し, 材料の破壊条件 (限界応力) が負荷速度に依存しないことを前提にすると，静的勒性 も含め, 動的勒性をある特定の位置における $\mathrm{R} て ゙$ 整理で きるという実験結果の根拠となるものである。

へき開破壊の破壊条件として, Weibull応力を用いた評 価が有効であることをこれまで示してきた11.14)が, Fig.4 の FEM 忍力解に対しても Weibull 応力 $\sigma_{w}$ を次式より求め た。

$$
\sigma_{w}=\left\{\sum \frac{V_{i}}{V_{o}} \sigma_{p s, i}\right\}^{1 / m}
$$

$V_{i}, \sigma_{p s, i}$ は $i$ 番目要素の体積と最大主応力であり, 塑性域 に対して計算を行った。また， $V_{0}$ は材料の単位体積であ るが、ここでは1とした。Fig.7(a)に得られたWeibull応 

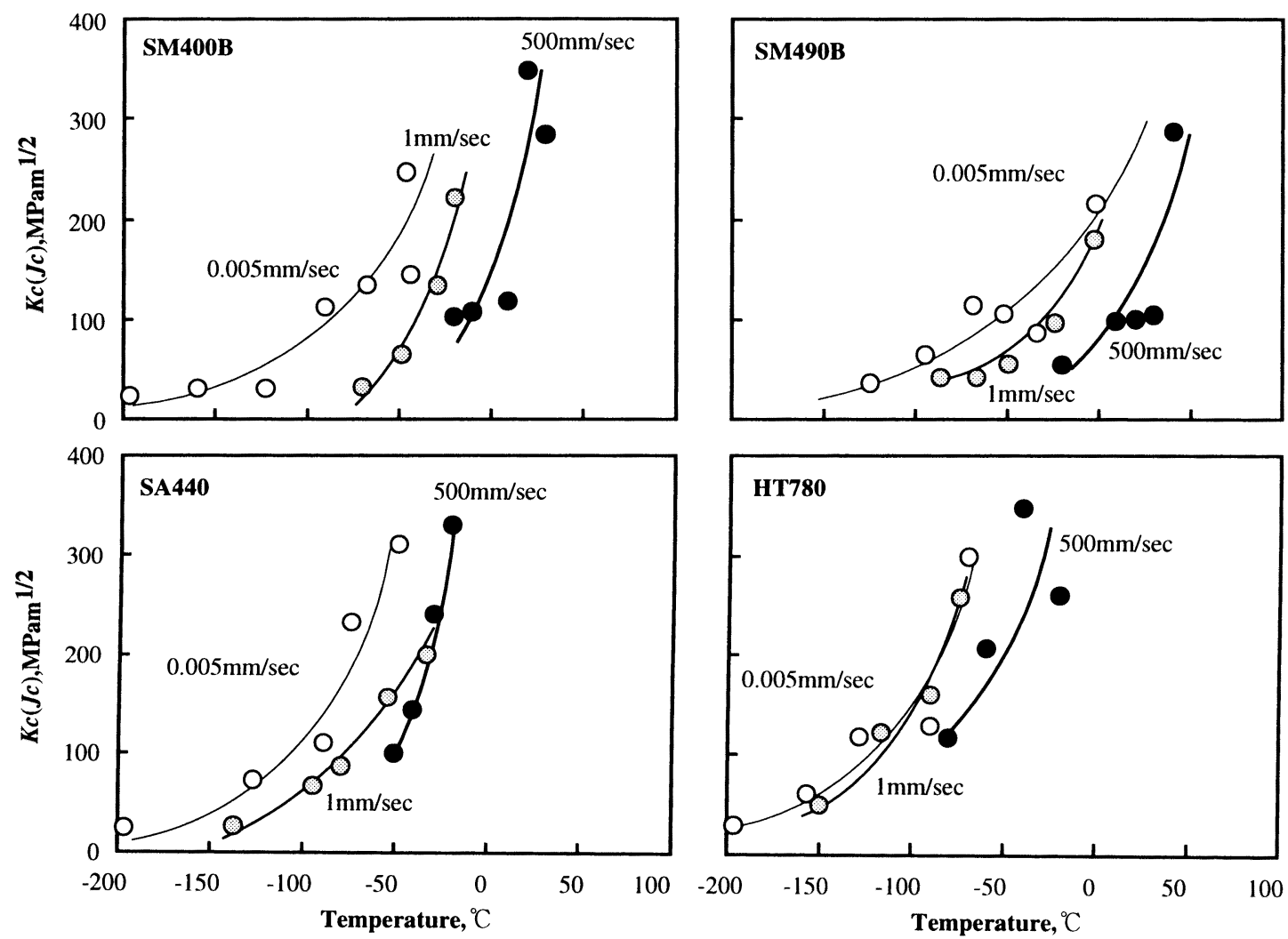

Fig.8 Temperature dependency of fracture toughness $K C(J c)$ for steels tested.

力 $\sigma_{w}$ を応力拡大係数 $K$ に対して整理した結果を示す。 Weibull 応力の算定に際しては, 限界 Weibull 応力 $\sigma_{w, c r}$ の Weibull 形状係数 $m$ ((3) 式の指数項) が必要となるが, 後 述する破壊勒性の温度依存性と降伏応力の温度依存性の 実験結果を基に後出の (4) 式から逆に推定した值を用い た。Fig.7(b) はFig.6(b) と同様にき裂先端から $100 \mu \mathrm{m}$ の位 置における弾性状態の $\mathrm{R}, \mathrm{R}_{e l s, \mathrm{X}=100 \mu \mathrm{m}}$ を基に算定した降 伏応力で無次元化したWeibull 応力 $\left(\sigma_{w} / \sigma_{y s, e l s ~ 100 \mu \mathrm{m}}\right)$ と応 力拡大係数 $K$ の関係である。Fig.6の結果からも容易に推 定できる結果ではあるが， $K$ と $\sigma_{w}$ に見られた大きな負荷 速度依存性（Fig.7(a)）は, き裂先端から 100 $\mu \mathrm{m}$ の位置に おける弾性状態の $\mathrm{R}$ を基に算定した降伏応力で無次元化 することにより，ほほ消失することがわかる。Fig.6と同 様ではあるが, Weibull応力をパラメータとして破壊条件

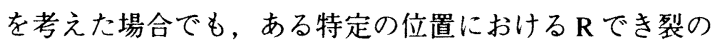
負荷速度レベルを代表させれば，動的負荷であっても静 的破壊勒性と同様に実験結果が整理でき得ることを示し ている。

3.2 破壊靭性および破壊条件（へき開破壊応力）の 負荷速度依存性

Fig. 8 に各供試材の勒性遷移曲線を示す。各材料とも変
位速度の増加に伴い遷移温度は上昇するが, その程度は 低強度の材料で顕著である。また, 遷移曲線が高温側にシ フトする場合, 全般的に破壊勒性の温度依存性が強くな る傾向にある。これは大変形破壊におけるき裂先端での 発熱散逸が高速変形のために抑えられたといった昇温効 果でも定性的に説明はできるが，高ひずみ速度では降伏 応力の温度依存性は強くなるといった $\sigma_{y s}-\mathrm{R}$ 関係を基に考 えても容易に推定できる傾向である。

3.1 節の議論の中でも述べたように, 材料のへき開破壊 条件 (限界応力) が負荷速度に依存するか否かは動的問題 への破壊力学の適用性にかかわる重要な問題となる。こ れまで著者らはFEM解析精度上の問題から $1 \mathrm{mmR}$ 円周切 欠き丸棒を用いて材料の限界Weibull 応力（破壊応力）を 評価してきた。Fig.9はこれまでと同様に $1 \mathrm{mmR}$ 円周切欠 き丸棒試験片を $-196{ }^{\circ} \mathrm{C}$ で負荷した場合の試験片最小断面 の公称応力と Weibull 応力の関係を D-FEM で算定した結 果である。実験は供試材の内, 強度の最も低いSM400B と 強度の最も高いHT780に関して 3 種類の変位速度で行っ たが，図中には対象材料の静的および準静的負荷の解析 結果と実験で得られた試験片破壊時の公称応力およびそ の結果をD-FEMの結果に照らし合わせて推定される限界 
Weibull 応力 $\sigma_{w, c r}$ の値を併せて示している。後述するよう に, 動的負荷 $(15 \mathrm{~mm} / \mathrm{sec})$ の奏験結果の一部はD-FEMで 弾性変形と推定される負荷状態で破壊しており, 塑性域 を積分して得られるWeibull応力が定義不能であった。静 的, 準静的の 2 条件だけではあるが，限界Weibull 応力 $\sigma_{w, c r}$ の負荷速度依存性は大きくはなく，第一近似的には 負荷速度によらず一定と扱えるものと考えられる。

著者らはこれまでに，最弱リンク概念に基づくWeibull 応力を破壊条件として，き裂先端の応力の解析解（HRR 解）を適用して得られる関係式9)

$$
K c=\mathrm{C}_{3} \sigma_{y s}\left(\sigma_{w, c r} / \sigma_{y s}\right)^{m / 4}
$$

を基礎として,静的破壊勒性の実験結果を解析し，より実 用性の高い実験式

$$
K c=\mathrm{C}_{4} \sigma_{c}\left(\sigma_{c} / \sigma_{y s}\right)^{\alpha}
$$

を提案してきた ${ }^{10,11)}$ 。 $\mathrm{C}_{3}, \mathrm{C}_{4}$ は材料定数である。(5) 式の $\sigma_{c}$ は $1 \mathrm{mmR}$ 円周切欠き丸棒を $-196^{\circ} \mathrm{C}$ で破壊させた場合の 破壊時の試験片内最大主応力であり, 寸法効果を考慮し た (4) 式中の $\sigma_{w, c r}$ とは物理的意味は異なるが, 同一試験 片形状を用いた中で負荷条件などの影響を議論する限り においては有効である。指数 $\alpha$ は材料定数であり，(4) 式 との対応から考えて破壊応力のWeibull形状係数 $m$ と同様 な物理的意味を持つものと考えられるが，解析的な予測 は困難であるので，実験結果が(5)式と最も相関するよう に定めている。

材料の破壊応力と破壊勒性の関連性を(5)式で議論する 場合, $\sigma_{c}$ の負荷速度依存性が問題となる。Fig.10(a), (b) は

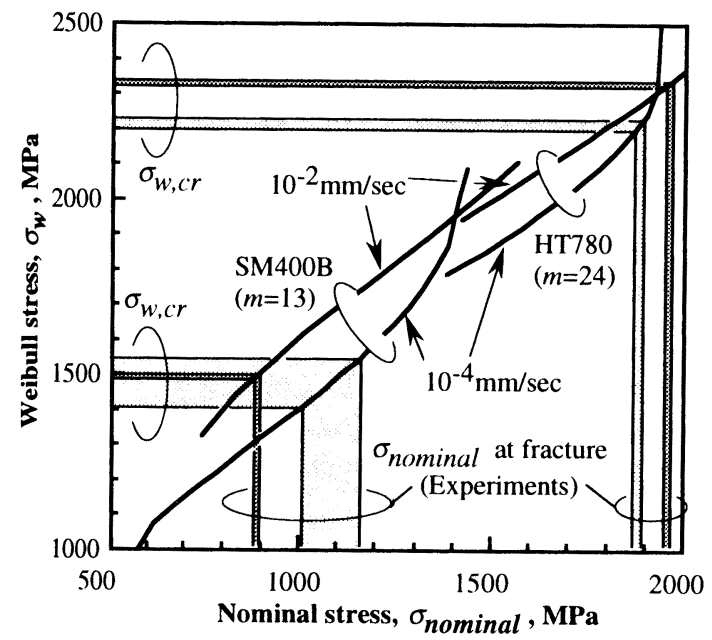

Fig.9 Relation between Weibull stress $\sigma_{w}$ and nominal stress for $1 \mathrm{mmR}$ notched round bar tensile specimen obtained by D-FEM and estimated $\sigma_{w, c r}$ from experimental results for $10^{-2}$ and $10^{-4} \mathrm{~mm} / \mathrm{sec}$.
Fig.9 と同様に $1 \mathrm{mmR}$ 円周切欠き丸棒試験片を $-196^{\circ} \mathrm{C} て ゙$ 負 荷した場合の切欠き底内部の最大主応力の変化を示した ものである。図中には実験結果をD-FEMの結果に照らし 合わせて推定されるへき開破壊応力 $\sigma_{c}$ の値を併せて示し ている。Fig.10(a)の動的負荷 $(15 \mathrm{~mm} / \mathrm{sec})$ においては, 破 壊がD-FEMで弾性変形と推定される負荷状態で起こって おり,信頼性にやや久ける結果となっている。これは極低 温での高速変形であるため, Fig. 3 に示した $\sigma_{y s}$-R 近似関数 において極めて小さな $\mathrm{R} の$ 領域にまで外挿して $\sigma_{y s}$ を推定 することになり，降伏応力を過大に評価したためである。 こうした問題点はあるものの, Fig.9と同様にこの結果で もへき開破壊応力 $\sigma_{c}$ の負荷速度依存性は大きくなく, 動 的勒性値の簡易推定に際しては, 試行的に $\sigma_{c}$ は負荷速度 によらず一定と扱うこととする。

\section{3 動的靭性の简易推定}

3.1 節で述べたように，簡易的にき裂先端から $100 \mu \mathrm{m}$ の 位置における弾性変形下の $\mathrm{R}, \mathrm{R}_{\text {els }, \mathrm{X}=100 \mu \mathrm{m}}$ を負荷速度レ ベルの参照值として用いることで, き裂先端近傍の応力

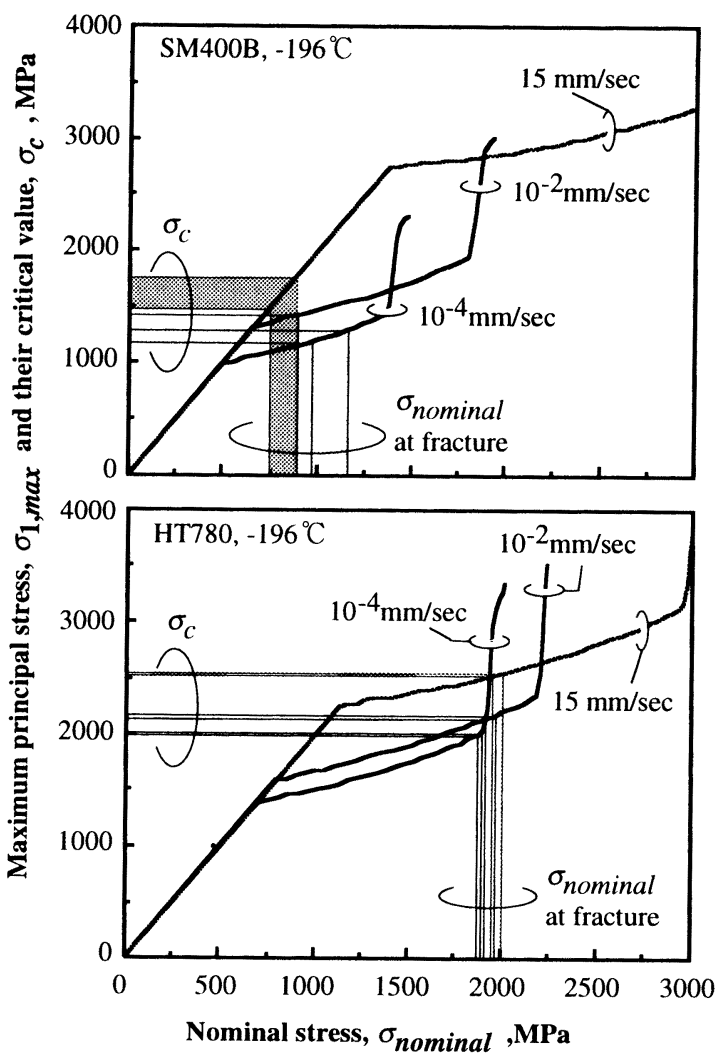

Fig.10 Relation between maximum principal stress $\sigma_{1, \text { max }}$ and nominal stress for $1 \mathrm{mmR}$ notched round bar tensile specimen obtained by D-FEM and cleavage fracture strength $\sigma_{c}$ estimated from experimental results for $10^{-4}, 10^{-2}$ and $15 \mathrm{~mm} / \mathrm{sec}$. 
は破壊力学パラメータで記述可能である。また, 3.2 節で 示したように，へき開破壊応力 $\sigma_{c}$ は負荷速度に大きくは 依存しないようである。また，(5)式の指数 $\alpha$ は材料中の 破壊発生核の分布に関連した一種の材料組織パラメータ であると考えられる ${ }^{11)}$ ため，(5)式を動的問題に適用する 場合, 破壊条件は一定で, 変形条件 $\left(\sigma_{y s}\right)$ のみに動的影 響を考慮することで, 動的破壊勒性をある程度表現可能 であると考えられる。

ここでは(5)式を基礎として, 静的破壊勒性の実験結果 のみから動的破壊勒性がどの程度推定可能かを検討する。 上述のように動的負荷の効果は (5) 式の降伏応力 $\sigma_{y s}$ のみ に与えることとし，その值は弾性変形におけるき裂先端 の $\mathrm{R}$ 分布（ひずみ速度分布）を参照し，き裂先端から $100 \mu \mathrm{m}$ の位置における值 $\left(\mathrm{R}_{e l s, \mathrm{X}=100 \mu \mathrm{m}}\right)$ を用いることに する。従って, 塑性仕事による発熱はまったく考慮されて いないが, 弾性変形におけるき裂先端の R 分布はひずみ 場の解析解を基に $d K / d t$ などの負荷条件から容易に求める ことができるものである。(5)式中の比例定数 $\mathrm{C}_{4}$ や, へき 開破壊応力 $\sigma_{c}$, 指数 $\alpha$ には動的負荷の効果はないものと して静的な実験結果，あるいは静的実験結果の相関より 求めた值をそのまま用いた。Fig.11は静的, 準静的, 動的 負荷速度における破壊勒性の実験值に対して, 上述の手 法で推定した值の相関を示したものである。破壊勒性が $K c=100 \mathrm{MPam}^{1 / 2}$ を超える範囲においては動的破壊勒性の 予測值は実験值に比較して保守的な值を与えているが, こうした簡単な推定手法でもある程度推定可能であるこ とがわかる。動的負荷における実験值が推定值よりも大 きくなったことの要因としては, (1)き裂先端での塑性仕
事による昇温効果, (2)大変形にともなう試験片の拘束緩 和効果, (3)動的負荷によるへき開破壊強度の変化,の3 点 が考えられる。(1)(2)の問題はD-FEMの詳細な解析結果か ら補正することは可能であり,この手法の推定精度向上 につながっていくものと考えられる。しかし, Fig.9,10の 結果において，へき開破壊強度は負荷速度の増加ととも に大きくはないが増加していることなど，傾向的には(3) の問題は実験結果の上でも現れている。鋼のへき開破壊 においては，炭化物あるいは粒界に生じた微小き裂が核 であるとさており，その形成には転位の集積が必要とな る15)。そのため, へき開破壊強度は形成された微小き裂寸 法のみでなく, Petchのモデル16)に代表されるように降伏 応力へ直接影響を与える結晶粒径といった材料組織因子 にも依存する ${ }^{10)}$ と考えられている。一方で, へき開破壊 強度の温度依存性は一般に小さいことが示されており， 降伏挙動に及ぼすひずみ速度増大の影響が温度低下と等 価な作用を与えるとすると，へき開破壊強度に及ほすひ ずみ速度の影響は小さいと考えることもでき得る。冷間 加工といった加工硬化においては, 塑性ひずみ量が比較 的小さい状況ではへき開破壊強度は導入されたひずみ量 に依存しない17)が，大きな塑性ひずみを導入した場合に は加工硬化に伴う降伏応力上昇と同様にへき開破壊強度 も上昇する ${ }^{18)}$ と報告されている。温度低下あるいはひず み速度増加と加工硬化とでは転位運動に対する金属物理 学的な影響機構は異なるが, へき開破壊強度のひずみ速 度依存性が無視し得るか否かも，加工硬化と同様にひず み速度の大きさ次第であると考えることが妥当であるよ うに思われる。この問題は破壊力学パラメータで動的破

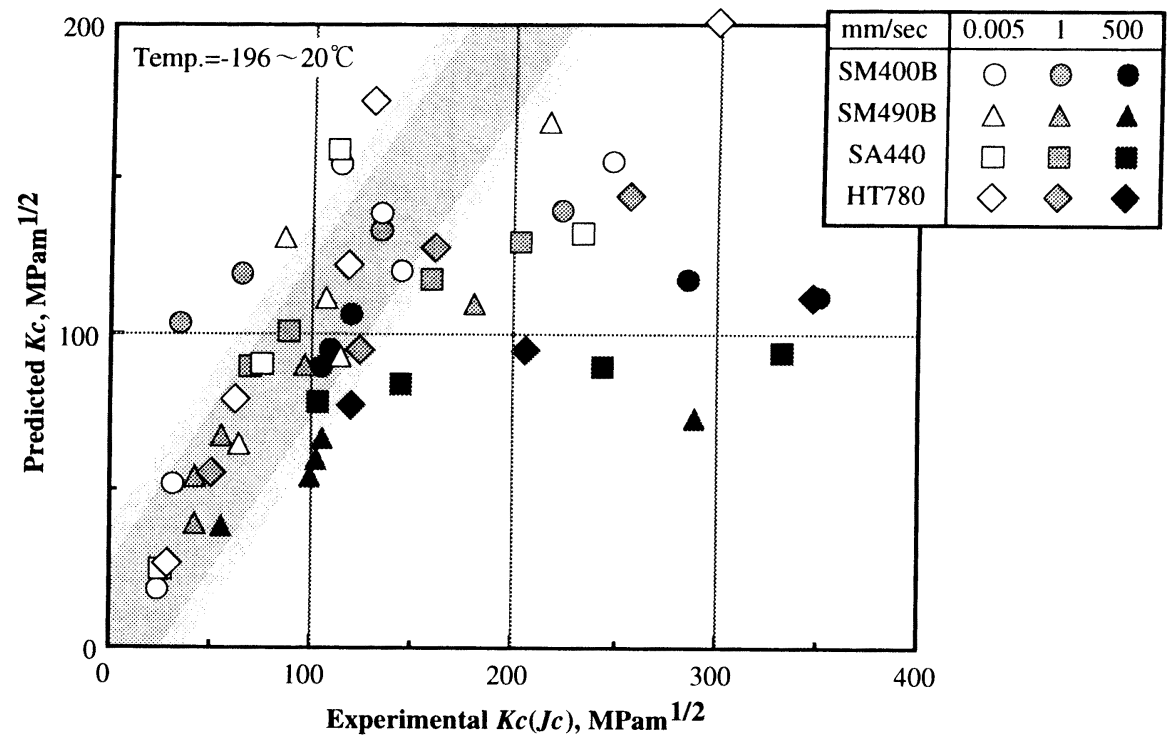

Fig.11 Correlation between experimental $K c(J c)$ in dynamic loading and predicted $K c$ from Eq.(5), considering dynamic loading effect into yield strength. 
壊勒性を評価する上で基本的かつ重要な問題であるため, へき開破壊強度のひずみ速度依存性が無視できなくなる ひずみ速度がどの程度かなど, 今後十分に検討していく 必要がある。

\section{4. 結 論}

動的有限要素法によりき裂先端近傍の応力場に及ほす 負荷速度の影響を解析し，動的破壊勒性がき裂先端のあ る特定の位置におけるひずみ速度一温度パラメー夕 (R) で整理できるという実験事実の理論的根拠を検討した。 さらにローカルアプローチを基礎とした実験式を基に簡 易的な動的破壊勒性の推定を試みた。得られた結論を以 下に要約する。

（1）負荷速度の増加に伴うき裂先端応力場の特異性の上 昇は，弾性のひずみ速度分布に基づくき裂先端から $100 \mu \mathrm{m}$ の位置における $\mathrm{R}$ パラメー夕， $\mathrm{R}_{e l s, \mathrm{X}=100 \mu \mathrm{m}}$ でほほ 基準化が可能である。

（2）応力拡大係数 $K$ と Weibull 応力の関係に及ぼす負荷 速度の影響も上記の $\mathrm{R}_{e l s, \mathrm{X}=100 \mu \mathrm{m}}$ で基準化が可能である。 これにより動的破壊勒性がき裂先端のある特定の位置に おける Rで整理できるという実験的事実の理論的検証が できた。

（3）降伏応力にのみ動的負荷の効果を考えることによ ク，ローカルアプローチを基礎とした実験式である程度 の動的破壊勒性の予測が可能である。

（4）破壊䩗性 $K c(J c)$ が $100 \mathrm{MPam}^{1 / 2}$ 以上では結論（3） の推定值は実験值より過小な值を与える。これは, 塑性拘 束の緩和あるいは発熱効果の他, へき開破壊強度のひず み速度依存性が原因として考えられる。

\section{謝辞}

本研究の実験の一部は名古屋大学大学院学生小松寛美 君 (現: 三菱重工業（株））によって遂行されたものであ る。ここに記して謝意を表する。

\section{参 考 文 献}

1）（社）日本溶接協会鉄鋼部会 APD 委員会（高梨晃 一主査) 中間報告 (1996)

2) P. E. Bennet and G. M. Sinclair : Parameter Representation of Low-Temperature Yield Behavior of Body-Centered Cubic Transition Metals, ASME Publication, 65-MET-11, (1965)

3）佐野：9\% $\mathrm{Ni}$ 鋼の破壊勒性に及はすき裂先端にお ける温度上昇の影響，鉄と銅，73，(1987），380386

4）豊貞, 後藤, 相良: 高速負荷時におけるき裂先端 近傍の局部温度上昇について, 日本造船学会論文 集, 170,（1991），651-663
5）豊貞, 藤井, 野原, 川口, 有持, 井坂：破壊勒性 に及ほすひずみ速度の影響, 日本造船学会論文 集，161，(1987），343-356

6）豊貞, 後藤：任意負荷速度下における破壊勒性値 推定法について, 日本造船学会論文集, 172 , (1992)，663-674

7）金田, 新村, 渡辺, 町田：鋼材の限界 C O D R及 ほすひずみ速度の影響, 日本造船学会論文集, 154, (1983), 434-441

8) H. T. Corten and A. K. Shoemaker : Fracture Toughness of Structural Steels as a Function of the Rate Parameter TInA/e, Transaction of the ASME Journal of Basic Engineering Series D, 89, (1967), 89-92

9) F. M. BEREMIN : A Local Criterion for Cleavage Fracture of a Nuclear Pressure Vessel Steel, Metallurgical Transaction A, 14A, (1983), 2277-2287

10）宮田, 田川, 粟飯原：低炭素鋼及び低合金鋼破壊 勒性の力学的定式化と引張強度特性との関係, 鉄 と鋼，71，(1995），583-588

11）田川, 宮田, 大塚：確率論的局所応力条件と破壊 じん性，材料，41，(1992)，1227-1233

12）南, 橋田, 豊田, 森川, 大村, 有持, 誉田: ロー カルアプローチの適用による構造用鋼の動的破壊 勒性評価一破壊制御設計へのローカルアプローチ の展開（第 3 報）一, 日本造船学会論文集, 184 , (1998)，457-468

13）後藤, 平澤, 豊貞: ひずみ速度, 温度を考慮した 構造用鋼構成方程式の簡易推定法, 日本造船学会 論文集，176，（1994），501-507

14) T. Miyata and T. Tagawa : Application of Local Approach to Quantitative Prediction of Degradation in Fracture Toughness of Steels Due to Pre-Straining and Irradiation, Journal De Physique IV Colloque C6, 6, (1996), C6-235-C6-242

15) E. Smith : The Nucleation and Growth of Cleavage Microcracks in Mild Steel, Proceedings of Physical Basis of Yield and Fracture, Physical Society of Oxford, (1966), 36-46

16) N. J. Petch : The Influence of Grain Boundary Carbide and Grain Size on the Cleavage Strength and Impact Transition Temperature of Steel, Acta Metallurgica, 34, (1986), 1387-1393

17）田川, 伊東, 宮田：予ひずみによる鋼材の破壊勒 性低下量の定量的予測と降伏比の影響, 溶接学会 論文集，14，(1996)，429-434

18) J. D. G. Groom and J. F. Knott : Cleavage Fracture in Prestrained Mild Steel, Metal Science, 9, (1975), 390400 